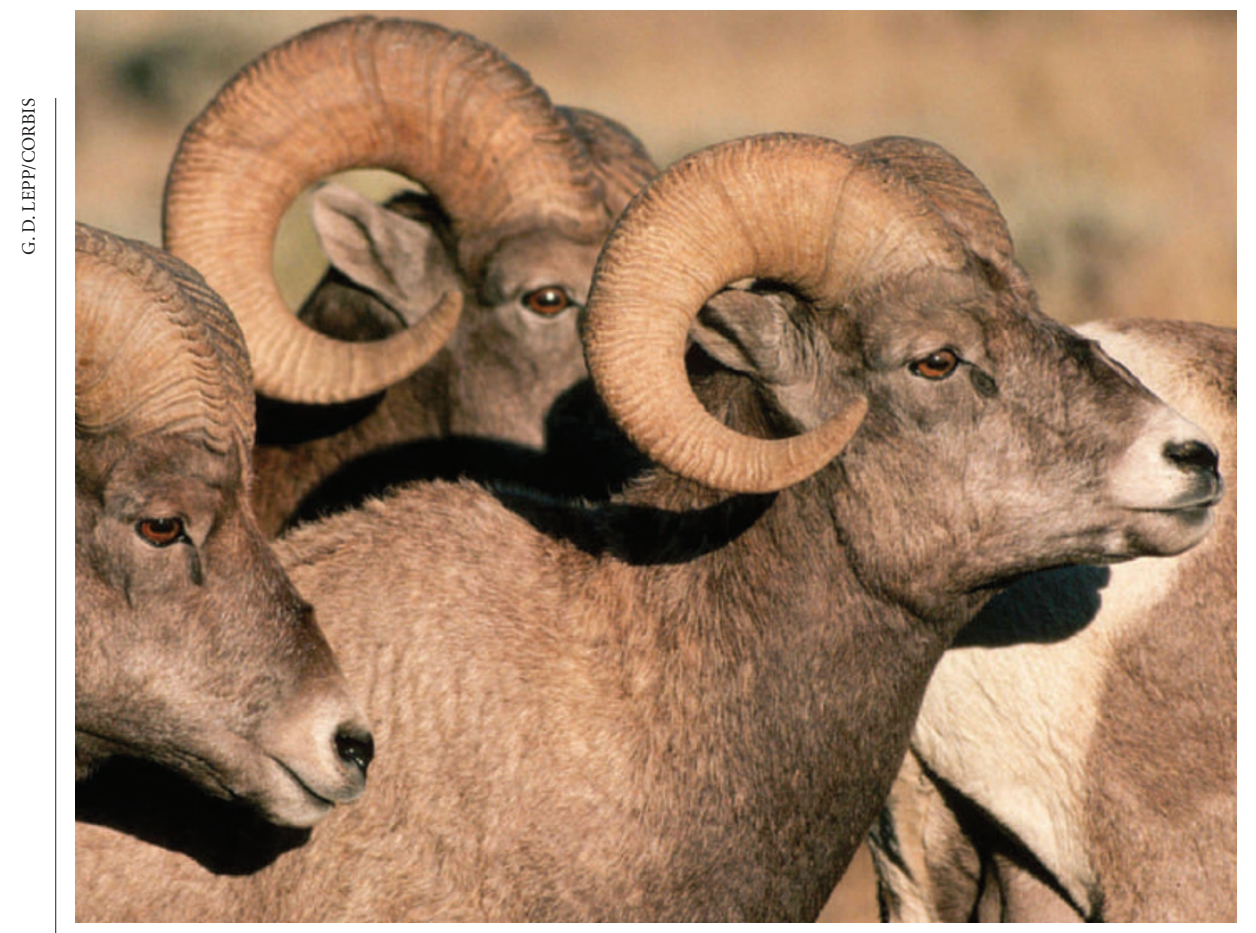

Thinking big: trophy hunters are removing rams with large horns from bighorn sheep populations.

\title{
Sheep horns downsized by hunters' taste for trophies
}

John Whitfield, London

The horns of some bighorn sheep are getting smaller, because hunters are picking off the most impressive rams before they reach their breeding peak.

A study of one sheep population in Canada shows that hunting can harm the gene pool of a species over just a few years. That means there should be tougher restrictions on what animals can be taken, says David Coltman of the University of Sheffield, UK. "For selection to be having this effect is of fundamental importance," he says.

Biologists have long suspected that hunting can affect animal evolution. Elephant poaching, for example, is thought to have led to an increase in the number of tuskless animals in Africa. And in Canada, the hunting of moose seems to have resulted in animals with smaller antlers.

To pin the relationship down, Coltman and his colleagues studied the sheep of Ram Mountain, Alberta. This Canadian province is home to the world's biggest bighorn sheep, and is a magnet to hunters. Since 1975, 57 of Ram Mountain's rams have been shot about $10 \%$ of all males in the population each year from 1975 to 1996. In 1996, the government restricted hunting to males with a large, 'full curl' of horns, which has reduced the cull to zero in recent years. Coltman looked at rams from 1971 to 2002, and found that horn size fell by about a quarter over this period (see page 655). Despite the recent drop-off in hunting, horn size has not recovered.

Large horns are generally correlated with large, healthy rams, says Coltman, so the effect on the population's genetics is probably deeper than the effect on horns alone. He suspects that hunting is also influencing mating behaviour, with fewer rams butting heads to fight for partners.

One reason for the change is that hunters prefer rams with large horns, as they make for more impressive trophies. But it could also be an accidental side effect of some hunting regulations. Restricting hunting to males with large horns is meant to limit the killing of animals that are not old enough to breed, but it also encourages the culling of animals that grow large horns early in life. "You force every hunter to harvest the very animal that you're trying to grow," says Kevin Hurley, a wildlife biologist with the Wyoming Fish and Game Department and executive director of the Northern Wild Sheep and Goat Council.

A better strategy may be to limit the number of hunting permits, argue both Hurley and Coltman. In the western United States, it is common to offer a limited number of permits for bighorn sheep by lottery or auction - the right to shoot a single ram frequently fetches as much as $\$ 100,000$.

Hunters are generally sympathetic to the need for management, says Kelly Semple, executive director of Hunting for Tomorrow, a coalition of hunting groups based in Edmonton,Alberta, as hunters do not want to drive large-horned animals into extinction. But she warns against generalizing Coltman's results to all species and locations.

\section{Europe dithers over regulations for stem-cell research}

Alison Abbott, Munich

Europe's debate on research using embryonic stem cells has ended for now in stalemate, leaving cell biologists uncertain as to where they stand.

The research ministers of the European Union's member states met on 3 December but failed to agree on whether European Union funding should be available for research using newly derived human embryonic stem cells. A moratorium on such funding will expire on 31 December.

In the absence of an agreement, the European Commission is now, at least in theory, free to fund future projects in its Sixth Framework Programme that exploit new cell lines. Although some of the European Union's member states are opposed to the use of new cell lines, the commission has said that it will think carefully about individual project proposals on a caseby-case basis.

In January, European Commission officials said that participants in the Sixth Framework Programme could use only embryonic stem cells that had been derived before the end of 2002, and gave the European Parliament and the Council of Ministers a year to develop clear rules on whether new cell lines produced from spare embryos from in vitro fertilization clinics could also be used.

Some countries, including the United Kingdom, allow such research to be carried out with public funds, whereas other nations, such as Germany, allow only existing cell lines to be used.

Last month, the European Parliament voted in favour of the use of newly derived cell lines, which some commissioners hoped would encourage waverers within the council also to vote liberally. But in the absence of a decision by the ministers, the European Commission will have to make its own rules about what it will allow in its next call for Framework proposals in June.

Ireland, which will take over the rotating presidency of the European Union from Italy in January, may call for another vote in the spring, but is under no obligation to do so. "Everything is still as open as it ever was," says Octavi Quintana Trias, head of life sciences at the commission's research directorate. 